\title{
Citizens, Consumers, Critique-al Subjects: Rethinking the "Statue Controversy" and Emily Murphy's The Black Candle (1922)
}

\author{
Tracy Kulba
}

Tracy Kulba écrit sur l'histoire politique et féministe complexe en Alberta, particulièrement sur des questions entourant les décisions juridiques controversées d'Emily Murphy issues de son oeuvre The Black Candle, qui a fort mauvaise réputation. Kulba écrit en tant qu'intellectuelle féministe et observatrice, mais aussi en tant que critique engagée.

We want women leaders today [1931] as never before, leaders who are not afraid to be called names and who are willing to go out and fight. I think women can save civilization. ${ }^{1}$

$$
\text { - Judge Emily Murphy }
$$

Commissioned to commemorate the $70^{\text {th }}$ anniversary of the Person's Case (1929), ${ }^{2}$ the Famous 5 monument (unveiled in Calgary on 18 October 1999) and the controversy that surrounded that monument's reception in the popular press represent in a highly compressed form the contested legacies of first-wave feminism. As suggested in the above quotation from its program of the unveiling, the Famous 5 Foundation framed the monument as an object of commemoration and a site of interpellation for contemporary "women leaders." The program briefly outlined the significance of the Person's Case as a landmark constitutional decision that definitively defined women as legal persons under the law in Canada, thus recognizing "the equality and importance of both men and women as nation builders." Including a small packet of bronze shavings in the program, the foundation further addressed the female spectator: "These are fragments of the original Famous 5 Monument. This piece of history will remind you to feel equal to the high and splendid braveries of the Famous 5." My fascination with this moment of exchange is twofold. On the one hand, I want to explore the slippage between interpellating the spectator 
as a feminist activist and as a citizen: the invitation to sit at the table of the "famous five" and to join their community of nation-builders. On the other hand, I am intrigued by the way in which history becomes manifest in the statue's objecthood, the way in which bronze shavings, which have been swept up off the floor and packaged, come to stand in as inspirational material by virtue of a history that they are imagined to embody.

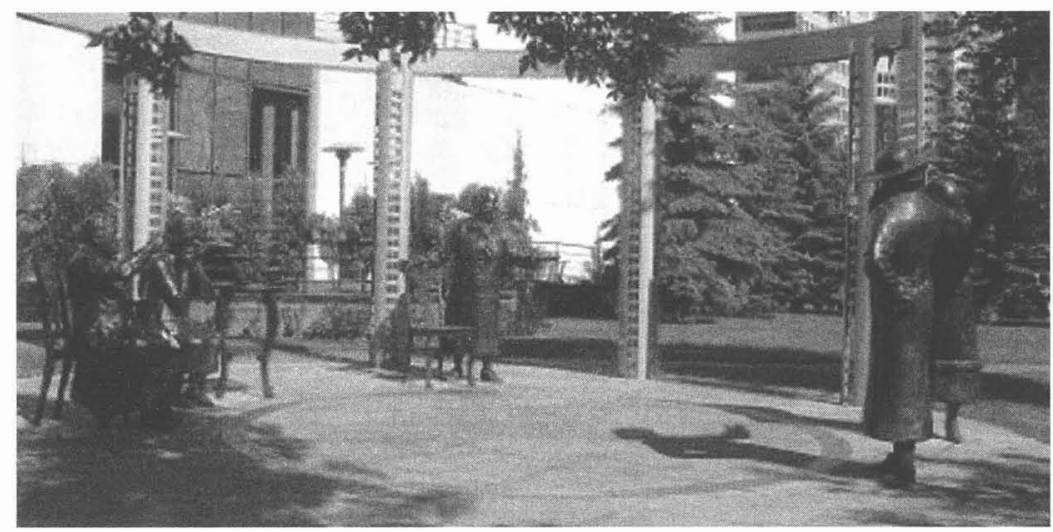

This paper then is an attempt to interrogate that interpellative, mystical moment. Against the ostensibly active political hailing represented by the statue's chair (which invites the spectator to sit at the table of the "famous five" and to imagine herself part of feminist nation-building in the present), I read the statue as a palimpsestic object, layered by competing historical narratives. Where the statue interpellates the spectator into a very particular mode of citizenship, inspired by the legacy of the "famous five," latent histories emerge in the discursive meaning-making that happens around the statue in the popular press. Instead of debating which narrative constitutes the right reading, my paper attempts to interrogate the subject positions that these narratives carve out for their imagined reader and to offer an alternative model. Toward that end, my paper begins by reading the statue; it maps out the ways in which the meaning of this statue was debated in the popular press; and it examines the particular representation of Emily Murphy's book The Black Candle (1922) in that controversy. By recognizing the histories latent within this monument, I attempt to de-mystify it as a fetishized object and to re-situate it in a complex network of social relations. Doing so, I suggest, shifts the statue's interpellation of feminists as citizen consumers and producers into a model of "critique-al citizenship" informed by a historical consciousness. ${ }^{3}$ 


\section{The Statue}

In October 1996, a foundation was established in Calgary with the object of marking the $70^{\text {th }}$ anniversary of the Person's Case and celebrating the achievements of the "famous five" who instigated that landmark decision: Nellie McClung, Louise McKinney, Henrietta Muir Edwards, Emily Murphy, and Irene Parlby. The Famous 5 Foundation commissioned a statue from Edmonton artist, Barbara Paterson, lobbied the Calgary city council for a prominent downtown site (Calgary's Olympic Plaza), and successfully petitioned Ottawa to accommodate a replica of this statue on Parliament Hill, transforming the statue into a national monument. ${ }^{4}$ Sculpted in bronze and monumentally proportioned, the statue imagines a specific event for the spectator so as to celebrate an ideal of legal and social equality.

Specifically, the statue dramatizes the hypothetical moment in which the "famous five" celebrate the British Privy Council's decision to legally recognize women as persons within the British North America Act. Rejecting the traditional pedestal, the monument stands at ground level in a broad circle, with the names of the individual women carved into the stones at their feet. Nellie McClung and Irene Parlby stand together with a newspaper declaring that "Women are Persons / Les Femmes sont des Personnes" while, seated at a table with teacups, Louise McKinney and Henrietta Muir Edwards toast the news. Aside (and directly in front of the spectator), Emily Murphy stands before an empty chair with her hand outstretched, implicitly inviting the spectator to enter their circle and to sit at their table. The figures are bronze and rough-hewn, with larger-than-life proportions. Outside the circle, alongside an acknowledgement of the statue's sponsors and a biographical sketch of each member of the "famous five," there are three placards that pedagogically sketch out a rough history of the case, framing it as an example and recognition of feminist nationbuilding. The last placard thus concludes:

\section{Yes, Women are Persons!}

On October 18, 1929, the Privy Council concluded: "...that the word 'persons' in Section 24 of the British North America Act, 1867, includes members of both the male and female sex..." The 'Persons' Case was a landmark victory in Canadian constitutional law. Its triumph symbolizes the equality and the importance of the contributions of both women and men as nation-builders. 
Working to highlight an inspirational narrative of feminist progress, this placard, and the statue generally, attempts to further the Famous 5 Foundation's self-proclaimed agenda to educate and inspire "women leaders" in the present.

The statue effects this interpellation from within the site of the domestic, framing the history of feminist struggle as a dialectical movement across the threshold of the private / public. Symbolically speaking, the "Person's Case" represents a recognition of women as equals under the law, as equals in public life. However, while the symbolic resonances of "personhood" suggest women's full entrance into a public political and economic community, the statue works also to interpellate the spectator into its community. It beckons her to enter its circle and sit in its chair at its table, where the hand of Emily Murphy grazes her shoulder. Locating this interpellation within the domestic scene of the sculpture, the statue repoliticizes that space as a site of political action while, indirectly, also focusing our attention on the public world outside its circle. Interpellating the spectator as a feminist and as a citizen, the statue's porous boundary invites transgression - literally within its space and on symbolic registers. This transgressive invitation thus imagines the mobilization of feminist agency in the public space of the nation while ostensibly redefining the parameters of citizenship, registering women's roles as mothers and homemakers as primary ones in the work of nation-building.

This dialectical movement is important because it marks the statue's attempt to reconcile a narrative of equality with a narrative of difference. Against the narrative of equality marked by the very "personhood" that the statue commemorates, the monument attempts to register a sense of gender difference. Where the traditional genre of the commemorative statue typically involves the elevation of a solitary figure - usually male - on a pedestal, this monument breaks with convention. It lowers the statue to the level of the spectator, democratizing its interpellation; it marks a collective victory rather than the life of a great individual; it replaces a phallic-like verticality with a circular, domestic space; and, it insists on the femininity of the women that it represents. While celebrating their equal status as "persons," the statue works to hold onto these women as women and celebrates the democratic agency of collective organizing. The statue interpellates "women leaders" into the present work of nation-building; it idealizes the possibilities of collective organizing as a democratic process; and it imagines a gendered model of citizenship that recognizes "the 
equality and the importance of the contributions of both women and men as nation-builders" (“Yes, Women are Persons!" placard).

This model of gendered citizenship, however, is fundamentally conservative in its call to arms. It does not, for instance, advocate a feminized model of citizenship that takes "women's experience, values and activities as the authoritative basis of what good citizenship looks like" (Voet 126) a call that would radically transform citizenship as a concept. It does not interrogate what it means by collective, democratic process. Neither does it consider the ways in which differences translate into ongoing inequalities. Instead, the gendered model that it does advocate is pluralistic, resonating in the discourse of diversity that Himani Bannerji critiques for "reading the notion of difference in a socially abstract manner, which also wipes away its location in history, thus obscuring colonialism, capital and slavery" (51). Rather than critiquing ongoing inequities or locating them in broader historical and systemic contexts, the statue celebrates the equal though different contributions of men and women in nation-building. On the one hand then, celebrating the nation-building efforts of these women from the locus of the domestic, garbing them in visual markers of femininity, the statue reduces difference to a gendered binary; it ignores the manifold other differences that nuance how men and women occupy those subject positions. On the other hand, because it abstracts difference as gender - rather than as unequal access to power or resources - the statue enables the recognition of an infinite chain of differences (for instance, attenuated by race, class or sexuality). However, it empties the concept of difference of a politicized recognition of inequality. Rather than interrogating that concept as a marker of unequal access, the statue suggests that spectators are uniformly equal in their differences, uniformly equal and protected as citizens of the nation. Itself a historical text, the statue thus ironically abstracts difference out of history so that it becomes a free-floating signifier.

Given this conservatism, the subject position into which the statue interpellates its imagined feminist citizen requires interrogation for its implication in dominant hegemonies of the nation. The chair invites the spectator to enter the circle of the "famous five" and to sit at their table; it invites the viewer to imagine herself a feminist nation-builder in the present, the inheritor of a feminist legacy. In taking that seat, however, the spectator also steps into a mode of citizenship identified as membership within a community - specifically, as membership within a national community. 
Commemorating the Person's Case, the statue appeals to an ideal of legal and social equality that invests women with protected individual rights and opportunities; however, in the celebration of difference as pluralism and the erasure of material inequity, those protected freedoms become rights of participation in existing political and economic structures. These structures remain neutral. Rather than calling for "material democracy - the equal access of all to social and economic resources" (Ebert, "Subalterity" 212), the statue celebrates the empowerment of women within capitalism. Beside the pedagogical placards, for instance, the statue highlights and thanks its female "funders": Ann, Roxanne and Jane McCaig; Lena Anne Hanen; Kiki Delaney; Senator Vivienne Poy; and Heather Reisman. Detailing their successes in the fields of business, psychiatry, and politics, ${ }^{5}$ the Famous 5 Foundation's website also made clear the foundation's commitment to corporate "mentorship":

In August of 1996, the F5F asked Sheila O'Brien, Senior Vice President for People, NOVA Corporation to organize a luncheon of key corporate women. After explaining our program for 5 luncheons to [educate] and fundraise, Sheila O'Brien stepped forward and agreed to sponsor the first luncheon and buy a number of tables for the series. Frances Peeples for AMOCO Canada, Drude Rimell from Alberta Energy Company, Linda Van Gastel from Pan Canadian and Hazel Gillespie from Petro-Canada also announced their support. The Foundation was launched due to the leadership and generosity of these five women. The following year, 1997-98, the Founding Funders continued their support and again, at the initiative of Sheila O'Brien, a new initiative aimed at young women was launched called Rising Stars!, again supported by these 5 women and their companies. We proudly announce the champions of the 1998-99 series: NOVA Chemicals Ltd., Petro-Canada, AMOCO Canada, AEC Canada, Enbridge and CIBC. (http://www.canuck.com/famous5/html/ acknowledgements.html)

This Rising Stars! Mentorship series is funded by major corporations with the pedagogical goal of inspiring and empowering young women as the "women leaders" of the future. While the statue gestures toward collective organizing, it ultimately produces the feminist subject in a discourse of protected individualism: as "persons." Rather than mobilizing that agency 
in the name of collective critique, the foundation works to interpellate feminists as citizen-consumers and producers. Collective critique stands as a narrative of first-wave feminism; nation-building in the present is imagined as participation in democratic capitalism. Rather than intervening into the present, the statue celebrates the myth of the already equal, defuses difference, and nowhere acknowledges the problematic racial and sexual politics of the "famous five" that dominated the "statue controversy."

\section{The Statue Controversy}

While it would be too simple to manufacture a single chain of cause and effect, the climate for the "statue controversy" was partially established by the Leillani Muir decision handed down from Alberta's Court of Queen's Bench in January 1996. Sterilized in 1959 under the Alberta Sexual Sterilization Act, Muir sued the Alberta government for procedural negligence and damages. The judge awarded her $\$ 740,780$ (plus $\$ 230,000$ in legal fees) in a decision that provoked controversial debates over how contemporary Canadian society should come to terms with its history. Representations of the case in magazines and newspapers described it as a denial of history ${ }^{6}$ or as a dire harbinger of future lawsuits stemming from current social policies. From the "opinion" page of The Vancouver Sun (01 Feb 1996), Trevor Lautens thus asked:

What are the politics of today that could be the lawsuits of tomorrow? ... How much will future courts award women denied children "because government counselors urged them to have abortions before they were old enough to understand the implications?" Or to white males denied jobs because of their race and gender? Or "an AIDS victim persuaded into a dangerous lifestyle by a government sex education course?" (qtg Ted Byfield)

For the Alberta government, the problem was similarly conceived in fiscal terms. In the face of a group lawsuit by sterilization victims that was launched in the wake of the Muir decision, the Alberta government decided to implement the Constitution's notwithstanding clause to limit potential payments - a move they revoked in the face of public condemnation (March 1998). This general debate about eugenics, liberal policies and the politics of historical accountability prepared the ground on which "famous five" members were evaluated by writers from various ideologi- 
cal camps, armed with quotations evidencing their problematic sexual and racial politics.

Given this lawsuit, the reaction it provoked from the Alberta government and public outcry that it provoked, the ground was ripe for a newspaper debate about the controversial eugenics policies advocated by individual "famous five" members - most significantly by Emily Murphy, a judge and social reformer who lobbied for Alberta's Sexual Sterilization Law (1928) and openly declared her support of eugenics as a social reform policy. While newspapers such as The Vancouver Sun fronted page one headlines asking, "Can a Hero be a Racist? Ms. Murphy's Dual Legacy" (16 May 1998), magazines like the Alberta Report appropriated race critiques to forward their own anti-abortion arguments. Link Byfield, for instance, charged that the sexual politics of contemporary feminists were replicating the mistakes of their flawed foremothers: "Just as some of the original feminists were blind to the personhood of Asians and the mentally handicapped, their successors are blind too. Why, for instance, do feminists never, ever champion the rights of other legally excluded human beings; most obviously, the unborn?" (13 Sept 1999). In the Calgary Herald, Peter Menzies argued that "in casting Emily Murphy in stone today, we make history in the present by excusing her racism in order to prove her feminism" (06 May 1998). Meanwhile, the Edmonton Journal (07 Jun 1998) ran an article by Paula Simons that reproduced a series of inflammatory passages from Emily Murphy's notorious book, The Black Candle:

These prolific Germans, with the equally prolific Russians and the still more fertile yellow races will wrest the leadership of the world from the British. Wise folk ought to think about these things for a while.

There is no doubt that the average Anglo-Saxon is filled with disgust and anger in reading how the Chinese betray their nation. ... We naturally classify these traitors as men of fishy blood who might easily be guilty of any enormity no matter how villainous.

Chinamen, Negroes and Jews thrive by reasons of the (drug) traffic ... One becomes especially disquieted - almost terrified - in the face of these things, for it sometimes seems as if the white race lacks both the physical and moral stamina to protect itself, and that maybe the black and yellow races may yet obtain the ascendancy. 
Similar passages appeared below Ken MacQueen's article in The Vancouver Sun, prefaced by an introduction to The Black Candle as Murphy's "1922 examination of the drug trade and its threat to the white race." In response to the controversy as a whole, the Vancouver North Shore Crisis Services Society changed the name of its women's shelter from the "Emily Murphy House" to the "Shelter, Advocacy, Growth and Empowerment" or SAGE House - to avoid alienating any group of women that might turn to them in need of support ("North Vancouver," The Vancouver Sun, 14 May 1998). And, in an attempt to justify their project and to address these charges of racism, the Famous 5 Foundation included a "commonly asked questions" section on their website in which they responded to the question "Were these heroes perfect?":

By studying the F5, we learn that people are complex beings, with strengths and weaknesses. The F5 operated from the basis of love, not hate. They tried many different ways to make life better for women and children and the majority of their initiatives were successful and have withstood the test of time. Some have not. Most Canadians believe that the achievements of these nation builders have significantly improved democracy in Canada and far outweigh their short comings.

[...]

Like most Canadians of the 1920's, Judge Murphy, for example, believed that Canada should develop as a British country. She admired her heritage, the British Empire, and wanted to continue that way of life. However, despite her preferences, Judge Murphy did not hate any other group of people. (http://www.famous5.org/ famous5/faq.html)

In one sense, this controversy emerged from internal feminist critiques that sought to make current feminist practices attentive to differences between women; in another sense, however, this controversy marked the appropriation of those critiques by conservative interests, who mobilized race to dismiss feminism and its insistence on women's right to control their own bodies. Realizing that doubleness helps to explain why liberalist notions of individual freedom and choice continue to matter for feminism. However, in the face of these charges, the Famous 5 Foundation responded by appealing to a dominant imagined community - the "most Canadians [who] believe that the achievements of these nation builders 
have significantly improved democracy in Canada and far outweigh their short comings" - and by appropriating multicultural discourse. In this logic, they asserted that Murphy was not a racist, she simply preferred her own heritage: "[that of] the British Empire, and wanted to continue that way of life." In so doing, the foundation re-framed Murphy's concern for the dominance of the white race into a more neutral rhetoric of "preference" that erased the production of normative British values as "Canadian" and the unequal relations of power that underwrote those preferences. Safely containing racism as a problem of the past, they invoked multiculturalist pluralism - for instance, in having a young Native girl inaugurate the interpellative chair at their unveiling ceremony in Calgary - to consolidate a narrative of progress for the present.

By contrast, the newspaper controversy insisted on recognizing Emily Murphy's problematic racial and sexual politics. From various ideological positions, columnists and interested citizens debated the meaning of the statue in light of this latent history. For many, including law professor Analise Acorn, the history meant that Murphy and her cohorts could not stand in as heroes for contemporary feminism. ${ }^{7}$ For others, the problem was one of contextualization; Murphy's politics needed to be re-situated as a product of her moment. For others, Murphy's eugenic policies marked the short-sightedness and ideological confusion of feminism generally. Manifesting a discursive struggle to determine "the meaning" of the statue, the controversy turned on a question of appropriateness: was the statue an appropriate monument for contemporary Canada and contemporary feminism? Implicitly working with a linear narrative of history, contributors to the debate either agreed that the statue was inappropriate -because the politics of these women were outdated - or argued for the "famous five's" ongoing value because of their contributions to a feminist narrative of progress. Both positions, however, constructed a feminist subject that was detached from the problems that Murphy came to represent. The problem thus remains: how does one negotiate the legacies of first-wave feminism as a historical subject? How does one mobilize the site of interpellation - as a feminist, as a citizen - in a historicized, critical mode?

Where the statue's chair suggests an interpellation of feminists as multicultural citizen-consumers, I want to reread this chair as a marker of absence, a silent site within the statue that asks to be filled - with bodies and with discourse. Reading this "silent site" as a marker of exclusion, I argue here that the statue indirectly represents a latent history of dis- 
avowal and exclusion. This doubleness speaks to what Homi K. Bhabha describes as the "ambivalence" that marks the nation as "the representation of social life rather than the discipline of social polity" (2). As a system of cultural signification then, Bhabha configures the nation "as a form of narrative" (2), a discursive form of ideology that "is always multi-accentual and Janus-faced" (qtg Volosinov 3). As such, the "study [of] the nation through its narrative address does not merely draw attention to its language and rhetoric; it also attempts to alter the conceptual object itself" (3). Reading the chair as an ambivalent site of interpellation, I suggest that we encounter an instance of the nation's narrative address - a representation of culture that interpellates us as readers. With the goal of re-thinking how we occupy that site of interpellation, I turn to representations of The Black Candle (1922) in the "statue controversy."

\section{The Black Candle (1922)}

Originally published as a series of five articles in MacLean's Magazine (1920), The Black Candle is a fascinating exposé of the drug-traffic trade in Canada. In its moment, it was tremendously influential, effecting legislative reform of Canada's existing drug laws and earning Murphy widespread respect as a social critic. The Secretariat of the League of Nations ordered copies of the text "for each member of its committees interested, in any way, in the traffic in narcotics" (Sanders 209). Murphy was recommended for the Advisory Committee of the League of Nations on the Opium Section, and, in Canada, she was invited by Sir Robert Borden (president of the Canadian League of Nations and former Prime Minister) to serve on a CLN committee. Lauded for its analysis and documentation, it was spiced with pictures of opium pipes, criminal profiles and "insensate" addicts - framed in a less objective rhetoric of racial degeneration and in sensational narratives of sexual danger (as illustrated in the passages published alongside Paula Simons' article in The Edmonton Journal). In the newspaper controversy that debated the statue, it was almost invariably the text that was referenced to prove Murphy's racism.

However, what is never commented on are the contradictions that mark The Black Candle. For instance, Murphy expresses clear anxiety about reports of middle-class white women sexually interacting with Chinese and Negro men. To explain the "amazing phenomenon of an educated gentlewoman, reared in a refined atmosphere, consorting with the lowest classes of yellow and black men," she deduces that addicts "seek the company of those who use the drug, and [avoid] those of their own social sta- 
tus" (17). Through the effects of the drug and the interaction, "the woman loses control of herself; her moral senses are blunted, and she becomes "a victim" in more senses than one" (17) - a loss of control that marks a moral and physical degeneration. However, while she maps a narrative of victimization onto the "educated gentlewoman," Murphy later rejects "white slavery" as an explanatory narrative for female drug use. ${ }^{8}$ Referencing her work as a judge, she notes that "[m]uch has been said of late, concerning the entrapping of girls by Chinamen in order to secure their services as peddlers of narcotics," but goes on to say that

[p]ersonally, we have never known of such a case ... Generally speaking the girl goes to the Chinaman because she has learned the drug habit and wants to get her drugs secretly ... It is not true however that a white girl or woman who is keeping to her own preserves is hunted like game, stalked to windward, and trapped by the Chinamen in order that she may be bent to his criminal purpose, or minister to his libidinous desire. (233)

Murphy worries about the strength of the British Empire and the "ascendancy" of the white race; however, she also "[has] no very great sympathy with the baiting of the yellow races or with the belief that these exist only to serve the Caucasian or to be exploited by us" (186). She works to secure a myth of the drug fiend as a degenerate, insane and inveterate liar, and she calls for reforms like deportation or lashings; but then she works to humanize that same addict (for instance, by reprinting letters written in the first person), and she calls for institutional reforms to "salvage" these individuals (treatment facilities, training for employment, follow-up care). While working with many of the same assumptions that locate the drug menace as a threat stemming from Chinatown, she also works to implicate the white middle classes in that problem - as active traffickers, users or as an indifferent populace.

The book thus does much more than simply equate "the drug menace" with the Chinese immigrant. It is marked by racist rhetoric but is conflicted in its attempt to describe and explain the problem. With the dual object of disseminating information and mobilizing public resistance, Murphy attempts to offer up a comprehensive analysis of the drug problem, exploring: how the materials are imported; how they are prepared; how they are sold; the terms that are used; statistics that suggest the extent of the problem; and the inadequacy of Canada's existing legislation. In the 
pseudo-scientific discourses of evolution and degeneration, she also attempts to suggest causes and effects of the problem. However, whether she is unable to sustain the myth of the Chinese drug fiend or whether she simply has to reject that myth on some level because of the real complexities of the problem, her attempts to adequately represent the drug-traffic trade repeatedly go beyond the myth making. As such, in speaking to the contradictions that mark this text, we can identify racist complicities, partial resistances and, even more interesting, the work that goes into producing and stabilizing mythical constructs that, on some level, are radically unstable.

Borrowing Constance Backhouse's notion of "racialization" - a practice of continually labeling individuals within racial categories (even as those categories continually break down) so as to secure differential access to power and resources - I want to suggest a mapping of The Black Candle's contradictions as unstable attempts to produce difference that are bound up with contemporary struggles over power and resources. Published in 1922 (only one year before the Chinese Immigration Act that virtually curtailed Chinese immigration to Canada until 1947), Murphy's book needs to be situated in a broader context of Canadian nation-building that was increasingly mobilized in exclusionary and differential terms. It contributed to that narrative address, simultaneously producing difference and forging affiliations with significant material consequences. Contributing to the nation's development, Chinese immigrants were a resource. Marked as undesirables by virtue of race, they were nonetheless desired as labourers. Their behaviours, however, were strictly policed, and texts such as The Black Candle increased the scope of that surveillance. Helping to manage this larger social contradiction, The Black Candle served hegemonic interests by producing narratives of degeneration and difference about Chinese immigrants. At root, however, these narratives were unstable and required constant reproduction.

The Black Candle does evidence Murphy's racism; however, it matters how our reading supports that statement. Instead of labeling Murphy a racist and disavowing her politics, I argue that it matters to attend to the productive mechanisms of her text - mechanisms that attempt to produce and secure racial constructs that are fundamentally unstable. Similarly, against the interpellation of feminists as citizen-consumers, the chair can also be read for its doubleness and instability as a marker of absence. It can become a productive site through which we interrogate race-making in the 
present. Resisting disavowal, this strategy shifts the reader/spectator into a different mode of understanding our relationship to history. It enables what Teresa L. Ebert describes as "critique-al knowledges": "the knowledges that aim at educating citizens for an inclusive democracy with equal social and economic access for all" ("Quango-ing" 1). "Critique," she states elsewhere, "is a mode of knowing that inquires into what is not said, into the silences and the suppressed or missing, in order to uncover the concealed operations of power and underlying socioeconomic relations connecting the myriad details and seemingly disparate events and representations of our lives" ("Subalterity" 215). In its ambivalence, the statue takes on new potential as a site of interpellation. Rather than beckoning the spectator into equal participation in the nation as feminist citizen-consumers, it has the potential to become an interventionary public space, contributing to the production of a critical feminist citizen.

\section{Notes}

${ }^{1}$ This quote is foregrounded in the program distributed at the Famous 5 Monument unveiling in Calgary (18 October 1999). I have attempted here to reproduce the layout and emphases of the quote as it stands in that program (produced and distributed by the Famous 5 Foundation).

${ }^{2}$ The Person's Case was a legal challenge, spearheaded by Emily Murphy, to clarify women's status as "persons" under the law. That is, although women had attained the right to vote and to hold public office, they were not considered eligible for the Senate because the British North America Act said that only "qualified persons" could be appointed. With the help of four other prominent women (Nellie McClung, Louise McKinney, Henrietta Muir Edwards and Irene Parlby), Murphy invoked an obscure section of the Supreme Court Act to petition the Canadian government for an Order-in-Council requiring the Supreme Court to rule on the question of whether or not women could be appointed to the Senate, which turned into a more symbolic ruling on women's standing as "qualified persons". The Supreme Court of Canada ruled that the term did not include women (April 1928); however, on a subsequent appeal to the British Privy Council, the ruling was reversed (18 October 1929). See Prentice et al, Canadian Women: A History, pp. 323-24.

${ }^{3}$ I take this term from Teresa L. Ebert, "Quango-ing the University: The End(s) of Critique-al Humanities." 
4 This monument - titled Women are Persons! - was unveiled on the Parliament grounds near the Senate building on 18 October 2000. The ceremony included: speeches by Governor General Adrienne Clarkson and Prime Minister Jean Chretien; performances by Inuit dance group Qilaujartiit, vocalists Measha Brueggergossman, Crystal Plamondon, Natalie Choquette, and Raylene Rankin (accompanied by the Calgary Girls Choir) and musical group, Barrage; a dramatic scene at the monument featuring the "famous five"; and, a staged initiation of the chair, involving a young Calgary girl who fundraised money to support the statue. Also present at the event were a handful of protesters from REAL women.

${ }^{5}$ See the "F5 Monument Funders" section on the Famous 5 Foundation's website (http:/ / www.famous5.org/famous5/monument_funding.html). ${ }^{6}$ Rob Martin, professor of law at the University of Western Ontario, for instance, asserted: "This case should have never gone to trial....You can't go back and litigate every historical outrage since the beginning of time....We're creating a social schizophrenia, judging every historical act according to today's moral standards" (qtd by Woodard).

7 Acorn argued that "Emily Murphy cannot function as a symbol of women's rights in the late $20^{\text {th }}$ century ... We can recognize her as a very important historical figure, but we can't expect her, at this moment in history, to be someone women can look up to as a heroine" (qtd in Simons). ${ }^{8}$ On the dominance of "white slavery" as a discourse, see Valverde's chapter, "The White Slavery Panic" and Backhouse's chapter, "Mesalliances' and the 'Menace to White Women's Virtue': Yee Clun's Opposition to the White Women's Labour Law, Saskatchewan, 1924."

\section{Works Cited}

Backhouse, Constance. Colour-Coded: A Legal History of Racism in Canada, 1900-1950. Toronto: U of Toronto P, 1999.

Bannerji, Himani. The Dark Side of the Nation: Essays on Multiculturalism, Nationalism and Gender. Toronto: Canadian Scholars' P, 2000.

Bhabha, Homi K. "Introduction: Narrating the Nation." Nation and Narration. Ed. Homi K. Bhabha. London: Routledge, 1990. 1-7. Byfield, Link. "Let Us Praise Famous Persons: Feminists Should Be Congratulated for Recognizing Grave Flaws in their Pioneers." Alberta Report 26.35 (13 Sept 1999): 2. 
Ebert, Teresa L. "Quango-ing the University: The End(s) of Critique-al Humanities: Part One." Cultural Logic 1.1 (Fall 1997): 30. <http://www. eserver.org/clogic/1-1/1-1index.html>.

-. "Subalterity and Feminism in the Moment of the (Post)modern: The Materialism Return." Order and Partialities: Theory, Pedagogy, and the "Postcolonial." Ed. Kostas Myrsiades and Jerry McGuire. Albany: SUNY P, 1995. 203-27.

Famous 5 Foundation. "Acknowledgements." 20 Oct $1999<$ http://www. canuck.com/famous5/html/acknowledgements.html>

_. "Commonly Asked Questions." 05 Jul $2001<$ http://www.famous5.org /famous5/faq.html>

Lautens, Trevor. "Sterilization award is not just about our past; it's about our future." The Vancouver Sun (01 February 1996): A13.

MacQueen, Ken. "Can a Hero be a Racist? Ms. Murphy's Dual Legacy." The Vancouver Sun (16 May 1998): A1, 9.

Menzies, Peter. "It's wrong to excuse Murphy's beliefs about race." Calgary Herald (06 May 1998): A14.

Murphy, Emily. The Black Candle. 1922. Intro. Brian Anthony and Robert Solomon. Toronto: Coles, 1973.

"North Vancouver." The Vancouver Sun (14 May 1998): B6.

Prentice, Alison et al. Canadian Women: A History. Toronto: Harcourt Brace Jovanovich, 1988.

Sanders, Byrne Hope. Emily Murphy: Crusader ("Janey Canuck"). Toronto: MacMillan, 1945.

Simons, Paula. "Heroine in a Black Hat." The Edmonton Journal (07 Jun 1998): F1.

Valverde, Mariana. The Age of Light, Soap, and Water: Moral Reform in English Canada, 1885-1925. Toronto: McClelland and Stewart, 1991.

Voet, Rian. Feminism and Citizenship. London: Sage, 1998.

Woodard, Joe. "No End to Doing Good." Alberta Report 22.29 (03 Jul 1995): 38-42. 